\title{
BELAJAR SPEAKING BERBASIS MULTIMEDIA (PENDEKATAN ANTROPOLINGUISTIK)
}

\section{Tasnim Lubis*}

Politeknik LP3I Medan, Indonesia

*Corresponding author: tasnimlubis@yahoo.com

\section{INFORMASI ARTIKEL}

\section{Sejarah Artikel}

Diterima: 6/3/2019

Direvisi: 31/5/2019

Disetujui: $2 / 6 / 2019$

Tersedia Daring: 19/6/2019

\section{Kata Kunci: \\ Pembelajaran Speaking \\ Tugas Video \\ Teks \\ Ko-teks \\ Konteks}

\section{ABSTRAK}

Penelitian ini bertujuan untuk mengetahui model pembelajaran speaking berbasis multimedia melalui pendekatan antropolinguistik. Pendekatan antropolinguistik mengombinasikan pembelajaran tuturan teks bahasa Inggris dalam pembelajaran speaking dengan koteks dan konteksnya. Hasil kuesioner, wawancara, dan tugas video merupakan data dalam penelitian ini. Data kuesioner diukur dengan menggunakan skala Likert. Untuk wawancara dan tugas video dianalisis dengan menggunakan pendekatan antropolinguistik yang menganalisis performansi berdasarkan teks, ko-teks, dan konteksnya. Selanjutnya data dianalisis dengan menggunakan model interaktif Miles dan Huberman yang terdiri dari kondensasi data, data display, dan verifikasi/simpulan. Hasil kuesioner menunjukkan bahwa mahasiswa menyukai pembelajaran speaking melalui penggunaan multimedia yang dikemas dalam bentuk tugas video karena mereka dapat langsung praktik menggunakan bahasa Inggris sekaligus dengan menggunakan ko-teks seperti gesture, intonasi, dan peralatan yang digunakan dalam berbicara seperti penutur asli (native speaker). Selanjutnya untuk konteks, mahasiswa mampu menghadirkan situasi formal untuk scene interview dan situasi nonformal sebelum dan sesudah scene interview. Pembelajaran speaking dengan penggunaan multimedia (tugas video) efektif untuk diaplikasikan di Politeknik LP3I Medan karena dapat membantu dalam menghilangkan sikap negatif dalam pembelajaran bahasa Inggris serta memberikan pemahaman secara langsung mengenai tahapan dalam mempelajari suatu topik pembelajaran.

\section{ABSTRACT}

\section{Keywords:}

Learning Speaking

Video Task

Text

Co-text

Context
The objective of the study is to describe the model of learning speaking based on multimedia through the approach of anthropolinguistics. The results of questionnaire, interview, and video are the data in this study. Then, they are analyzed by using interactive model proposed by Miles and Huberman. It consists of data condensation, data display, and verification/conclusion. The questionnaire is measured by using Likert scale. Meanwhile, both interview and video task are analyzed through the approach of anthropolinguistics. Anthropolinguistics focuses on a performance which covers text, co-text, and context. The result of the questionnaire shows that students like to learn speaking by using multimedia (video task) because they are able to practice speaking English directly; they can also learn about cotext such as gesture, intonation, and equipment which are nativelike. In terms of the context, students able to perform in both formal and non-formal situations. A formal situation occurs at a job interview scene; meanwhile, an informal situation arises 
before and after the job interview scene. Learning speaking by using multimedia (video task) is effective to be applied at Politeknik LP3I Medan as it is able to minimize negative attitudes. In addition, it directly explains the steps in the learning process.

Copyright@2019, Tasnim Lubis This is an open access article under the CC-BY-3.0 license
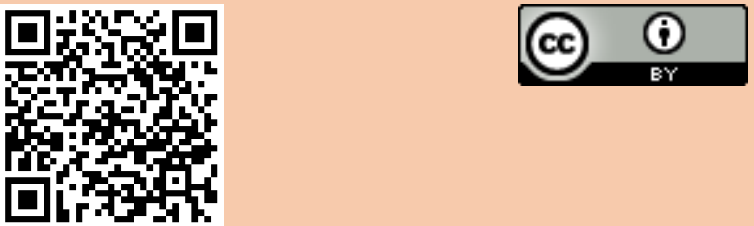

\section{PENDAHULUAN}

Mengajarkan speaking tidak hanya memberikan informasi atau menyampaikan berbagai jenis ekspresi (kalimat) dalam berbicara, akan tetapi juga sekaligus memberitahukan cara penyampaian serta situasi penyampaian. Mahasiswa di Politeknik LP3I Medan terdiri dari multi etnik seperti Batak, Melayu, Jawa, Aceh, dan juga India. Cara mereka bertutur yang masih kental dengan logat Batak misalnya, sangat memengaruhi cara mereka berbicara ketika menggunakan bahasa Inggris. Demikian pula halnya dengan etnik lainnya. Hal ini merupakan salah satu hambatan mereka dalam aktif berbicara menggunakan bahasa Inggris, karena mereka malu jika intonasi dan lafal pengucapan yang dipengaruhi aksen bahasa ibu mereka.

Melalui observasi awal, peneliti menemukan bahwa mahasiswa di Politeknik LP3I Medan sebagaian besar sangat suka menertawakan temannya ketika temannya melakukan kesalahan dalam berbicara bahasa Inggris seperti salah dalam pengucapan, aksen yang digunakan, kemudian ketika melakukan jeda karena lupa atau tidak mengetahui kosakata atau cara mengekspresikan maksudnya. Fenomena yang terjadi adalah hadirnya sikap negatif seperti saling menertawakan meskipun yang menertawakan juga tidak memiliki kemampuan dalam berbicara. Dampaknya adalah mahasiswa menjadi kurang motivasi belajar dengan bersikap pasif dan memilih diam ketika belajar atau menunjukkan sikap tidak perduli (dengan menjawab sekedarnya atau juga tertawa untuk menjaga muka di hadapan teman-temannya) (Muslem \& Abbas, 2017). Hal ini tentu saja merupakan sikap yang tidak baik karena akan menghambat mereka dalam pemerolehan pembelajaran speaking. Lubis (2015a) menyatakan bahwa membangun sikap positif adalah langkah pertama yang harus dilakukan sebelum dosen memutuskan untuk menerapkan strategi dalam pembelajaran. Selain itu, untuk mengetahui pendapat siswa atau pandangan mereka tentang bahasa Inggris, maka sangat penting dosen dapat memberi tahu mereka tentang penggunaan bahasa Inggris dalam kehidupan mereka sendiri. Pendapat serupa, Karahan (2007) menjelaskan bahwa sikap positif dalam memelajari bahasa Inggris menjadikan pelajar memiliki orientasi positif terhadap pembelajaran bahasa Inggris. Dengan demikian, sikap dapat memainkan peran yang sangat penting dalam pembelajaran bahasa karena mereka akan mempengaruhi keberhasilan atau kegagalan siswa dalam pembelajaran mereka. Secara umum, Chaer (2015) menyatakan bahwa hasil pembelajaran bahasa Inggris atau bahasa asing di Indonesia tidak menggembirakan. Tentunya hal ini membutuhkan strategi yang baik dalam mengajarkan bahasa Inggris sebagai bahasa asing yang melibatkan sikap dalam memelajarinya (Siregar \& Tiarina, 2013).

Meskipun demikian, tetap masih ada beberapa mahasiswa yang mau dan berani untuk berbicara dalam bahasa Inggris baik untuk merespon dan menjawab pertanyaan dari dosennya ataupun menunjukkan ketertarikan dengan mengajukan pertanyaan. Melalui wawancara mendalam dengan beberapa mahasiswa tersebut, peneliti mendapatkan informasi bahwa mereka sebelumnya pernah 
mendapatkan pembelajaran bahasa Inggris yang intensif seperti kursus, les privat dan memiliki komunitas yang gemar berbahasa Inggris. Dengan demikian, mereka memiliki sikap yang baik dalam memelajari bahasa Inggris di kelas karena memiliki motivasi yang kuat dan rasa percaya diri yang baik karena telah memiliki modal dalam berkomunikasi dalam bahasa Inggris. Melalui penelitian sebelumnya, mahasiswa dengan motivasi yang tinggi dan memiliki lingkungan yang berbahasa Inggris seperti les/kursus bahasa Inggris, akan lebih mudah untuk memeroleh pelajaran dan meningkatkan bahasa Inggris mereka (Lubis \& Syahril, 2015). Berbanding terbalik dengan pelajar yang memiliki sikap negatif dalam memelajari bahasa Inggris seperti kurang percaya diri untuk berbicara, takut berbuat salah, dan takut diejek oleh teman-temannya akan sangat sulit dalam memeroleh pelajaran bahasa Inggris karena mereka tidak mau praktik sama sekali. Meskipun mereka mengetahui banyak kosakata, akan tetapi semua kosakata yang pernah diketahui dan diingat akan hilang jika mereka tidak mau mempraktikkannya dalam kehidupan sehari-hari. Untuk mengatasi hal tersebut, peneliti mencoba untuk menggunakan strategi dengan menggunakan multimedia untuk praktik speaking mahasiswa.

Dewasa ini, mahasiswa sangat akrab dengan penggunaan gadget, sehingga media ini dapat menjadi media untuk pembelajaran speaking karena dapat didokumentasikan sehingga dapat ditampilkan. Tujuan penelitian ini adalah untuk mendeskripsikan model pembelajaran speaking berbasis multimedia (dalam hal ini adalah tugas video) dengan menggunakan pendekatan antropolinguistik pada mahasiswa Politeknik LP3I Medan. Penelitian sebelumnya yang menggunakan multimedia antara lain tentang penggunaan power point dalam pengajaran speaking yang sangat membantu dalam proses pembelajaran (Siregar \& Tiarina, 2013). Melalui media ini pelajar menjadi lebih tertarik untuk belajar dan terhindar dari rasa bosan dan proses pembelajaran di dalam kelas menjadi lebih menyenangkan. Selanjutnya, penelitian tentang penerapan media audio visual dalam pembelajaran bahasa Inggris menemukan bahwa media audio visual digunakan dalam persiapan silabus yang mencakup peralatan, RPP (Rencana Pelaksanaan Pembelajaran), LCD (Liquid Crystal Display), laptop dan materi yang digunakan pada tentang penggunaan power point dalam pengajaran speaking mengatakan bahwa microsoft power point sangat membantu dalam proses pembelajaran (Wahyuningsih \& Haris, 2014). Penelitian ini merupakan pengembangan dari penelitian sebelumnya yaitu (Lubis, 2015b) yang meneliti tentang pembelajaran speaking dengan tujuan menyediakan konsep inovatif dari pembelajaran speaking dengan menggunakan teknologi melalui tugas video.

Yang membedakan penelitian ini dengan penelitian sebelumnya adalah penggunaan media video sebagai media praktik speaking mahasiswa yang dianalisis dengan menggunakan pendekatan antropolinguistik untuk meneliti secara lebih komprehensif, karena melibatkan tuturan dan cara menuturkan bahasa Inggris dalam pembelajaran speaking. Pendekatan antropolinguistik merupakan interdisiplin yang dapat digunakan untuk menganalisis peristiwa tutur secara lengkap karena mengandalkan performansi. Performansi adalah aktivitas berbahasa yang dapat diamati secara langsung. Tampilan mahasiswa dalam memroduksi tuturan dalam bahasa Inggris merupakan performansi mereka yang dapat diteliti secara teks, ko-teks, dan konteks (Fauzi, 2016). Sibarani (2015) menyatakan bahwa struktur dan formula unsur verbal dan non-verbal tradisi lisan dapat dijelaskan melalui pemahaman struktur teks, ko-teks, dan konteksnya dalam suatu performansi, sehingga pemahaman bentuk itu juga menjadi pemahaman keseluruhan performansi tradisi lisan.

\section{METODE}

Penelitian ini menggunakan metode kualitatif. Kuesioner dibagikan kepada mahasiswa Politeknik LP3I Medan tingkat I tahun ajaran 2014/2015 untuk mengumpulkan data mengenai pendapat mereka dalam menggunakan video dalam pembelajaran bahasa Inggris. Pendapat mereka diukur dengan menggunakan skala Likert. Selanjutnya, video yang dihasilkan 
merupakan data audio-visual yang dilakukan mahasiswa dalam mempraktikkan speaking. Pemilihan tugas video diberikan untuk membantu mahasiswa bekerja dalam kelompok, sehingga mereka dapat saling membantu dan bekerjasama dan membangun rasa percaya diri. Video yang ditampilkan dapat dibuat di lokasi yang mereka inginkan dan nyaman pada saat melakukannya. Dari semua video yang dibuat, lokasi yang mereka pilih adalah rumah, tempat kos mereka dan kampus Politeknik LP3I Medan. Hal ini menunjukkan bahwa mereka mencari lokasi dimana hanya ada mereka dan lokasi yang mereka kenal. Dengan demikian, wacana yang dilakukan sangat aplikatif. Selanjutnya, topik yang diberikan adalah yang dipelajari pada semester tersebut.

Teknik pengumpulan data dilakukan melalui kuesioner, wawancara mendalam, dan tugas video. Kuesioner yang didistribusikan kepada mahasiswa untuk memeroleh jawaban umum mengenai model yang diterapkan dalam pembelajaran speaking. Untuk melengkapi informasi secara mendalam, maka wawancara dilakukan untuk mendapatkan jawaban yang lebih spesifik. Selanjutnya, melalui data video yang dihasilkan diberikan penilaian untuk kemampuan speaking. Data dianalisis dengan menggunakan model interaktif Miles dan Huberman yang terdiri dari data kondensat, data display dan verifikasi/simpulan. Pendekatan antropolinguistik digunakan sebagai koridor yang melibatkan teks, ko-teks dan konteks dalam berbicara. Teks terdiri dari ujaran-ujaran yang dihasilkan mahasiswa. Ko-teks berkaitan dengan setiap elemen yang mendampingi teks seperti intonasi, gesture, kinesik, dan peralatan yang digunakan. Konteks berkaitan dengan lokasi dan waktu serta situasi yang diciptakan seperti dalam situasi formal atau nonformal.

\section{HASIL DAN PEMBAHASAN}

Kuesioner yang dibagikan memberikan gambaran hasil pendapat mengenai aplikasi tugas video yang diberikan. Sikap siswa terhadap bahasa Inggris Amerika Meksiko di program imersi terstruktur menyatakan bahwa sikap bahasa siswa dapat diukur dengan menggunakan kuesioner yang terdiri dari empat elemen; sikap terhadap guru ELD (Pengembangan Bahasa Inggris), sikap terhadap buku-buku ELD, sikap terhadap tugas dan sikap ELD terhadap kelas ELD dan juga pertanyaan pribadi (Martinez, Pérez, \& Madrid, 2013). Hasil penelitian kuesioner menunjukkan bahwa mahasiswa-mahasiswa menyukai pembelajaran melalui tugas video. Dengan menggunakan skala Likert, dapat dilihat bahwa angka yang ditunjukkan mendekati angka maksimal. Diagram 1 dan Diagram 2 menunjukkan secara simbolis uraian hasil kuesioner.

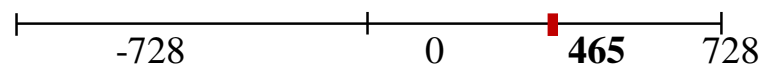

\section{Diagram 1 \\ Skala Likert Kelas Pertama}

\begin{tabular}{llll}
\hline-728 & 0 & $\mathbf{4 5 6}$ & 728
\end{tabular}

\section{Diagram 2 Skala Likert Kelas Kedua}

Angka 465 dan 456 mendeskripsikan jumlah yang mendekati angka 728. Hal ini berarti mahasiswa menyukai belajar dengan menggunakan multimedia (audio-video) yang didokumentasikan, sehingga mereka dapat melihat hasil pekerjaan mereka yang melibatkan 
pembelajaran berbicara dan kerjasama dalam menyiapkan teks, ko-teks, dan konteksnya. Melalui wawancara mendalam, mahasiswa menyatakan bahwa mereka dapat melakukan perencanaan sebelum mempraktikkan bahasa Inggris, sedangkan jika di dalam kelas, mereka harus menjawab dengan spontan.

Pembelajaran speaking dengan menggunakan multimedia dalam penelitian ini adalah pembuatan video oleh mahasiswa untuk membantu mereka dalam membangun kepercayaan diri dalam berbicara menggunakan bahasa Inggris karena mereka bekerja dalam kelompok dan saling membantu, dapat melakukan persiapan sebelum berbicara, dan dapat melihat hasil pekerjaan mereka karena didokumentasikan. Pada saat persiapan membuat video, mereka melakukan hal-hal seperti merencanakan peran, merencanakan teks yang akan diucapkan mencakup teks, bagaimana mengucapkan, bagaimana gesture yang akan dilakukan, kemudian mempersiapkan peralatan yang dibutuhkan mencakup kostum, ruangan, dan hal lainnya yang mereka anggap dibutuhkan untuk video tersebut, setelah semuanya selesai, mereka praktikkan. Setelahnya, mereka dapat melihat hasilnya dan mereka dapat mereview bersama. Jika terdapat kekurangan atau ingin hasil yang lebih baik, mereka akan melakukan pengulangan baik secara perbagian atau secara keseluruhan.

Ada proses yang dilakukan dalam pembuatan video untuk pembelajaran speaking yaitu perencanaan, persiapan, tindakan, dan review. Sebenarnya proses tersebut adalah tahapantahapan yang harus dilakukan seorang pembelajar sebelum melakukan proses pembelajaran. Diharapkan melalui tugas pembuatan video yang diberikan, mahasiswa mendapat pelajaran dan nilai bahwa suatu hasil (kemampuan) membutuhkan tahapan-tahapan untuk mendapatkannya. Tugas membuat video tidak hanya membuat mereka menghasilkan sesuatu tidak hanya menghasilkan produk, akan tetapi juga menjadi suatu pembelajaran tentang proses yang harus dijalani.

Untuk hal tersebut, dosen memiliki peran dalam menjelaskan kepada mahasiswa mengenai sikap belajar yang baik yaitu melakukan persiapan seperti mengetahui dan mencoba mencari tahu mengenai topik yang akan dipelajari, kemudian memiliki sikap bekerja sama yang diwujudkan dengan mengikuti pelajaran dengan baik, saling membantu (contohnya mendengarkan dan menyimak ketika teman menjawab pertanyaan atau yang diberikan dan memperbaiki jika teman mengucapkan kosakata yang salah), serta mereview kemampuan yang telah diperoleh.

Pembelajaran berbasis multimedia juga membuat suasana belajar menjadi lebih menarik dan jauh dari rasa bosan karena melibatkan banyak aspek seperti visual, audio, dan psikomotrik. Penerapan media audio visual dalam pembelajaran bahasa Inggris menemukan bahwa media audio visual digunakan dalam persiapan sillabus yang mencakup peralatan, RPP, LCD, laptop dan materi yang digunakan pada permulaan semester (Wahyuningsih \& Haris, 2014). Tujuannya adalah agar pelajaran yang disampaikan menjadi lebih jelas dan lebih mudah dipahami peserta didik. Demikian pula di Politeknik LP3I Medan, pengajaran dengan menggunakan multimedia akan mempercepat proses pemerolehan materi. Dengan demikian, dengan pembelajaran selama empat semester diharapkan dapat menggunanakan bahasa Inggris dengan baik, sehingga mampu berkompetisi di dunia kerja kelak. Permasalahan umum adalah mahasiswa tidak mau berbicara ataupun praktik berbicara, karena mereka malu jika mereka melakukan kesalahan dalam berbicara seperti pengucapan ataupun melakukan banyak jeda. Hal ini terkait dengan pengalaman mereka belajar bahasa Inggris di sekolah formal sebelumnya. Harmer (2010) menyatakan bahwa pelajar dewasa datang dengan banyak pengalaman belajar sebelumnya yang dapat mempengaruhi kemajuan mereka. Siswa yang memiliki pengalaman belajar negatif di masa lalu mungkin gugup dengan pembelajaran baru (Utomo, 2017).

Untuk hasil video, dengan menggunakan pendekatan antropolinguistik yang mengutamakan performansi sebagai data. Tidak mungkin memelajari suatu bahasa tanpa 
mengetahui bagaimana mereka menuturkannya karena makna dari tuturan sangat tergantung dari konteks ketika tuturan tersebut diproduksi (Lubis \& Abus, 2017). Dengan demikian, untuk menemukan strukturnya, performansi adalah satu-satunya cara untuk melihat dan mendeskripsikan sebuah tradisi lisan. Dilanjutkan dengan penelitian yang menekankan pada pentingnya memelajari tentang performansi dikarenakan manusia memiliki kreativitas dalam mengekspresikan ide, pikiran dan perasaannya dalam cara yang literal dan juga nonliteral (Lubis, Sibarani, Lubis, \& Azhari, 2019). Performansi adalah produk akhir dari manusia yang dapat diamati. Performansi mencakup teks, ko-teks, dan konteks. Kata dalam teks biasanya merujuk kepada setiap pesan, tuturan, tulisan yang sepanjang apapun yang menunjukkan bentuk sebuah satuan secara keseluruhan (Halliday, Matthiessen, \& Halliday, 2014). Teks juga merupakan sebuah unit dalam penggunaan bahasa. Tidak hanya unit gramatikal, seperti sebuah klausa atau kalimat, akan tetapi lebih besar yang merujuk kepada makna.

Selanjutnya, ko-teks secara umum adalah komponen-komponen yang mendampingi teks. ko-teks mencakup paralinguistik, proksemik, dan juga pealatan yang digunakan pada saat bertutur. Berdasarkan makna dalam Kamus Linguistik, ko-teks diartikan sebagai kalimat atau unsur-unsur yang mendahului dan/atau mengikuti sebuah unsur lain dalam wacana. Kartikasari (2016) menyatakan bagaimana cara seseorang mengucapkan lambang-lambang verbal, paralinguistik ini dapat menjadi faktor yang mempengaruhi persepsi interpersonal. Kemudian, konteks yang berkaitan dengan ruang dan waktu pada saat ujaran disampaikan. Konteks dalam hal ini juga disebut situasi. Menurut Finnegan (2013), performansi berada dibanyak situasi, dari yang terstruktur dan terencana dengan baik, kemudian informal hingga yang mendadak (impromptu).

Melalui video, performansi yang dihasilkan menunjukkan bahwa teks yang dihasilkan dari percakapan pada tugas video sudah menunjukkan pola komunikasi yang baik seperti memiliki pembukaan, isi, dan penutup dengan berbagai variasi komunikasi (Ismail, Lahinta, \& Novian, 2013). Selanjutnya, penggunaan teks dilengkapi dengan ko-teks yang disesuaikan pada acara formal (dalam hal ini pada saat wawancara kerja). Contoh teks antara interviewer dan interviewee dapat dilihat sebagai berikut.
Interviwer
(memperformansikan gerakan menyilakan duduk). Why do you want me to work in the company?
Interviewee
True. Thank you very much sir.
Interviwer
Please your $C V$. (dengan mengangkat tangan meminta $\mathrm{CV}$ )
Interviwee
This sir. (menyerahkan CV)
Interviwer
(membuka CV) Ok. Please tell your self.
Interviwee
Thank you sir. I will start to introduce my self. My name is Zularmansyah. I age 19 years old. I am fresh graduated from LP3I. My hobby is hiking. I can work available team or personal. Thank you sir
Interviwer : Why do you want work in this company?
Interviwee $\quad:$ I want develop my skill. Because I see the quality of your company is good.
Interviwer : Right. Have you ever worked before?
Interviwee $\quad$ : Yes I did...
(Dan seterusnya yang diakhiri dengan meminta interviewee untuk keluar sebentar karena interviewer ingin mengevaluasi hasil wawancara)

Dari contoh teks di atas, dapat dilihat bahwa terdapat beberapa teks yang kurang sesuai seperti pertanyaan yang diajukan interviewer diawal yaitu "Why do you want me to work in the company?". Ketika ditanyakan, sebenarnya maksud mahasiswa yang berperan sebagai 
interviewer adalah "Do you want to apply a job in this company?". karena gesture yang ditunjukkan setelahnya adalah mempersilahkan interviewee untuk duduk. Selanjutnya kalimat yang disampaikan oleh interviewee mengenai usianya yaitu "I age 19 years old" yang kemudian diperbaiki pada saat pembelajaran di kelas menjadi I am 19 years old. Dari teks yang dihasilkan terdapat beberapa kesalahan (error sentences) seperti struktur kalimat, dan koherensi yaitu ketidaksesuaian antara pertanyaan dan respon yang diberikan. Akan tetapi, untuk pola komunikasi yang diperformansikan sudah cukup baik karena memiliki pembuka, isi, dan penutup. Untuk ko-teks, gerakan tubuh (gesture dan kinesik) menunjukkan peran masingmasing sebagai interviewer dan inetrviewee serta suara (pitch) yang standar untuk percakapan dalam sebuah wawancara kerja. Selanjutnya, mahasiswa juga menggunakan pakaian formal (seragam) sebagai perlengkapan yang mengindeks kepada sebuah acara wawancara kerja. Kemudian, situasi yang diciptakan adalah situasi formal dengan melakukan percakapan di ruang kelas yang dianggap seperti ruang kantor.

Secara keseluruhan, mahasiswa mengetahui bahwa untuk topik job interview adalah kalimat-kalimat apa yang biasanya ditanyakan, kemudian, bagaimana menjadi interview dan interviewee. Bahkan menariknya, ada satu kelompok yang menampilkan performansi interviewee yang tidak baik sebagai contoh, sehingga di akhirnya, interviewee tersebut tidak mendapatkan kesempatan untuk dipekerjakan. Hal tersebut menunjukkan bahwa mahasiswa juga mengetahui hal-hal yang harus dihindari seperti kalimat, cara penyampaian yang tidak sopan, gesture yang tidak sopan dan yang lainnya (Iragiliati \& Rachmajanti, 2016). Mereka mengetahui tata cara wawancara kerja (budaya bersikap) yang berterima. Ini merupakan kreatifvitas mahasiswa yang menunjukkan bahwa mereka tidak hanya mementingkan tugas untuk berbahasa Inggris, akan tetapi juga melibatkan unsur nilai di dalam tugas tersebut (Sugiharto, 2016).

Hal tersebut diketahui melalui pembelajaran di dalam kelas dan juga informasi yang mereka cari sendiri di internet. Mahasiswa menjadi mandiri dan memiliki usaha yang baik untuk memeroleh pengetahuan mengenai hal yang dipelajarinya. Kemudian mereka mencoba memahami dan meniru performansi seperti yang diperolehnya. Performansi yang mereka tampilkan merupakan suatu hal yang kreatif dan juga disesuaikan dengan budaya yang mereka pahami sebelumnya. Hal ini sesuai dengan pendapat Hymes dalam Duranti (2009) yang menyatakan bahwa performansi adalah sesuatu yang kreatif, berwujud, dan berterima. Melalui pendekatan antropolinguistik, dapat diketahui bahwa performansi yang dihasilkan mahasiswa sudah cukup baik karena melalui proses persiapan, latihan, dan pembuatan video. Dengan demikian, pembelajaran speaking melalui penggunaan multimedia khususnya tugas video dapat membantu mahasiswa dalam memotivasi dan melakukan tahapan dalam suatu pembelajaran.

\section{SIMPULAN}

Berdasarkan hasil penelitian dan pembahasan, dapat disimpulkan bahwa pembelajaran speaking berbasis multimedia dengan menggunakan pendekatan antropolinguistik, merupakan model pembelajaran yang efektif karena mengajarkan berbicara tidak bisa memisahkan antara teks yang diujarkan. Akan tetapi, harus menyatu dengan ko-teks yang digunakan serta dilengkapi dengan konteksnya. Melalui tugas video, mahasiswa dapat mempraktikkan pengetahuan dan pengalaman yang dimiliki dalam berbicara sekaligus dapat melihat dan mereview kembali ketika terdapat kesalahan ataupun ketidaksesuaian dalam praktik speaking. Selanjutnya, pembelajaran tidak hanya terpusat kepada teks-teks ujaran saja, akan tetapi cara menuturkan dan situasi menjadi satu kesatuan yang berakhir pada performansi yang dapat diteliti secara komprehensif. 
Melalui model pembelajaran bahasa Inggris yang demikian, timbulnya sikap positif yang sangat penting dalam proses belajar contohnya memiliki keinginan untuk mempelajari dan mau berdiskusi dikarenakan langsung mengalami permasalahan ataupun hambatan pada saat mengerjakan tugas. Dengan tambahan motivasi yang diberikan oleh dosen diharapkan sikap negatif dalam pembelajaran speaking dapat dihilangkan, sehingga proses dan hasil pembelajaran menjadi lebih baik.

\section{DAFTAR PUSTAKA}

Chaer, A. (2015). Psikolinguistik Kajian Teoritik. Jakarta Rineka Cipta.

Duranti, A. (2009). Linguistic Anthropology: A reader. New York: Cambridge University Press.

Fauzi, I. (2016). The Application of Multimedia-Based Presentation in Improving Students' Speaking Skill. Journal of ELT Research, 1(1), 103-112.

Finnegan, R. (2013). Oral Traditions and the Verbal Arts: A Guide to Research Practices. London: Routledge.

Halliday, M., Matthiessen, C., \& Halliday, M. (2014). An Introduction to Functional Grammar: Routledge.

Harmer, J. (2010). How to Teach English. ELT journal, 62(3), 313-316.

Iragiliati, E., \& Rachmajanti, S. (2016). Developing Supplementary Multimedia-based Listening Materials For The Seventh Graders. Jurnal Pendidikan: Teori, Penelitian, dan Pengembangan, 1(5), 940-947.

Ismail, S. R., Lahinta, A., \& Novian, D. (2013). Peningkatan Sistem Pembelajaran Public Speaking for Teens dengan Pemanfaatan Teknologi Multimedia KIM Fakultas Teknik, $3(1), 1-11$.

Karahan, F. (2007). Language Attitudes of Turkish Students Towards the English Language and its Use in Turkish Context. Çankaya University Journal of arts and sciences, 1(7), 73-87.

Kartikasari, G. (2016). Pengaruh Media Pembelajaran Berbasis Multimedia terhadap Motivasi dan Hasil Belajar Materi Sistem Pencernaan Manusia: Studi Eksperimen pada Siswa Kelas V MI Miftahul Huda Pandantoyo. Jurnal Dinamika Penelitian: Media Komunikasi Penelitian Sosial Keagamaan, 16(1), 59-77.

Lubis, T. (2015a). Experiential Learning Through Video Tasks in Learning Speaking (case Study: Students at LP3I Medan). Paper presented at the Seminar Nasional Inovasi dan Teknologi Informasi (SNITI) 2015.

Lubis, T. (2015b). Students Language Attitude toward English. Jurnal Bisnis Edukasi, 4(1), 110-128.

Lubis, T., \& Abus, A. F. (2017). Teknik Mind Mapping dalam Pengajaran Bahasa di Sekolah Dasar Muhammadiyah 18 Medan. Paper presented at the KOLITA 15, Jakarta.

Lubis, T., Sibarani, R., Lubis, S., \& Azhari, I. (2019). The Performance of Nandong in Simeulue Island. International Journal of Research and Review, 5(12), 283-289.

Lubis, T., \& Syahril. (2015). Students Reading Ability toward TOEIC Score. Paper presented at the Seminar Nasional Industrialisasi Madura, Madura.

Martinez, D. U., Pérez, J. G., \& Madrid, D. (2013). Attitudes of Mexican American Students Towards Learning English as a Second Language in a Structured Immersion Program. Porta Linguarum, 3(1), 205-221.

Muslem, A., \& Abbas, M. (2017). The Effectiveness of Immersive Multimedia Learning with Peer Support on English Speaking and Reading Aloud. International Journal of Instruction, 10(1), 203-218. 
Sibarani, R. (2015). Pendekatan Antropolinguistik terhadap Kajian Tradisi Lisan. RETORIKA: Jurnal Ilmu Bahasa, 1(1), 1-17.

Siregar, I. K., \& Tiarina, Y. (2013). Creating Media to Teach Speaking by Using Microsoft Power Point Journal of English Language Teaching, 1(3), 18-21.

Sugiharto, T. (2016). Rancang Bangun Pengembangan Aplikasi Pembelajaran Bahasa Inggris Berbasis Multimedia Interaktif. Jejaring: Jurnal Teknologi dan Manajemen Informatika, 1(1), 22-30.

Utomo, A. (2017). Model Pembelajaran Berbasis Multimedia pada Pembelajaran Listening Comprehension Indutstri Inovatif Jurnal Teknik Industri, 5(1), 27-39.

Wahyuningsih, M. G. S., \& Haris. (2014). Penerapan Media Audio Visual dalam Pembelajaran Bahasa Inggris (Studi Kasus di SMPN 3 Bawen). Jurnal Teknologi Pendidikan dan Pembelajaran, 2(1), 12-21. 